\title{
Peramalan Indeks Harga Konsumen Dengan Metode Singular Spectral Analysis (SSA) dan Seasonal Autoregressive Integrated Moving Average (SARIMA)
}

\author{
Deltha Airuzsh Lubis ${ }^{1}$, Muhamad Budiman Johra², Gumgum Darmawan ${ }^{3}$ \\ Magister Statistika Terapan, Universitas Padjajaran, Jl. Dipati Ukur No.35, Bandung 40132 \\ delthalubis@gmail.com¹, muhamadbudiman8271@gmail.com², gumstat@gmail.com ${ }^{3}$
}

DOI:https://doi.org/10.15642/mantik.2017.3.2.74-82

\begin{abstract}
Abstrak
Indeks Harga konsumen (IHK) merupakan indikator yang digunakan untuk mengukur inflasi maupun deflasi dari sekelompok barang dan jasa secara umum. Peramalan IHK menjadi penting sebagai deteksi dini dalam menghadapi lonjakan harga. Penelitian ini menggunakan metode SSA dan SARIMA. SARIMA merupakan model parametrik yang membutuhkan berbagai asumsi sedangkan SSA merupakan teknik nonparametrik yang bebas dari berbagai asumsi namun kedua metode tersebut mensyaratkan adanya pola musiman pada data. Berdasarkan hasil penelitian, metode SSA dengan length window (L) sebesar 24 dan grouping sebanyak 4 (1 kelompok trend dan 3 kelompok musiman) dan model SARIMA berorde $(0,1,1)(0,1,1)_{6}$ merupakan model yang tepat dan andal dalam peramalan IHK Kota Padangsidempuan. Peramalan IHK Kota Padangsidimpuan untuk 5 bulan ke depan dengan metode SSA dan SARIMA $(0,1,1)(0,1,1)_{6}$ menunjukkan pola tren yang cenderung meningkat tetapi peramalan pada bulan ke-5 dengan metode SSA menunjukkan lonjakan nilai IHK yang tinggi atau akan tejadi inflasi yang tinggi.
\end{abstract}

Kata kunci: ARIMA, IHK Seasonal, Singular Spectral Analysis

\begin{abstract}
Consumer Price Index (CPI) are the indicators used to measure the inflation and deflation of a group of goods and services in general. Forecasting CPI to be important as early detection in facing price hikes. This study uses the SSA and SARIMA. SARIMA a parametric model that requires various assumptions while SSA is a nonparametric technique that is free from a variety of assumptions, but both methods require seasonal patterns in the data. Based on the research results, methods of SSA with length window(L) of 24 and a grouping of 4 (1 group of seasonal and 3 groups of ternds) and SARIMA models of order $(0,1,1),(0,1,1) 6$ is the most accurate and reliable models in forecasting CPI to the value Padangsidempuan City. Forecasting CPI Padangsidimpuan City for the next 5 months with SSA method and SARIMA $(0,1,1),(0,1,1) 6$ shows the pattern of trend is likely to increase but forecasting the 5th month with SSA method showed a surge in the value of CPI high or high inflation will occurs.
\end{abstract}

Keywords: ARIMA, CPI, Seasonal, Singular Spectral Analysis

\section{Pendahuluan}

Indeks Harga konsumen (IHK) merupakan nilai indeks yang menggambarkan rata-rata perubahan harga dari suatu paket barang dan jasa yang dikonsumsi oleh rumah tangga dalam kurun waktu tertentu. Perubahan IHK dari waktu ke waktu menggambarkan inflasi maupun deflasi dari barang dan jasa secara umum. Data IHK secara resmi dirilis oleh pemerintah melalui Badan Pusat Statistik (BPS) setiap bulannya yang mencakup 65 kota di Indonesia.

Kebutuhan barang dan jasa pada musimmusim tertentu seperti idul fitri, tahun ajaran baru dan sebagainya selalu melonjak sehingga menyebabkan peningkatan harga pada musim- 
musim tersebut. Keadaan seperti ini akan mempengaruhi perubahan nilai IHK dan membentuk pola musiman di setiap tahunnya. Dalam melakukan analisis deret waktu pada data IHK sebaiknya melibatkan efek musiman tersebut, diantaranya dengan menggunakan metode SSA dan SARIMA. Pemodelan SSA merupakan metode nonparametrik sehingga lebih fleksibel dalam penggunaannya dan terhindar dari berbagai asumsi seperti stasioneritas, independensi dan normalitas residual sebagaimana pada model SARIMA yang parametrik [1]. Selain itu, SSA efektif dalam meminimalisir eror [2]. Dalam metode SSA tidak ada model yang dibangun seperti model SARIMA sehingga parameter pada SSA berupa panjang window (L) dan banyaknya grouping (r).

Kota Padangsidempuan merupakan salah satu kota yang berada di bagian paling selatan di provinsi Sumatera Utara yang menjadi jalur perdagangan yang penting bagi beberapa kabupaten di sekitarnya. Kota ini memiliki jarak yang paling jauh ke ibukota provinsi yaitu 448 $\mathrm{km}$ bila dibandingkan kota lain yang menjadi kota penghitung inflasi seperti Sibolga $(382 \mathrm{~km})$, Pematangsiantar $(128 \mathrm{~km})$, dan Medan $(0 \mathrm{~km})$ [3].

Peramalan IHK menjadi penting untuk melihat bagaimana perkembangan IHK di Kota Padangsidempuan, sehingga dapat menjadi deteksi dini dalam mengatasi lonjakan harga yang mungkin terjadi.

\section{Kajian Teori}

\subsection{Singular Spectrum Analysis (SSA)}

SSA merupakan teknik analisis data deret waktu yang terkini dan powerful dalam menggabungkan analisis deret waktu, statistik multivariat, geometrik multivariat, sistem dinamis dan proses signal. Penerapan SSA kian meluas dari bidang matematika dan fisika ke bidang ekonomi dan matematika keuangan, dari ilmu metrologi dan oseanologi ke ilmu sosial dan riset pemasaran [4].

SSA dapat mengatasi beberapa masalah seperti, menemukan trend pada resolusi yang berbeda; smoothing; mengekstrak komponen musiman; mengekstrak secara simultan pola siklis; mengekstrak periodesitas dengan amplitudo yang beragam; menemukan struktur data pada data deret waktu yang pendek dan mendeteksi perubahan titik [4].

\subsection{Seasonal Autoregressive Integrated Moving Average (SARIMA)}

Model ARIMA yang melibatkan efek musiman didalamnya disebut juga dengan model SARIMA. Secara umum, model SARIMA ditulis dengan persamaan berikut [6]:

$$
\begin{aligned}
& \Phi_{P} B^{S} \phi_{p}(B)(1-B)^{d}\left(1-B^{S}\right)^{D} Z_{t}= \\
& \theta_{q}(B) \Theta_{Q}\left(B^{S}\right) a_{t}
\end{aligned}
$$

dimana:

$\begin{array}{ll}\phi_{p}(B) & : \text { AR non seasonal } \\ \Phi_{P} & : \text { AR seasonal } \\ (1-B)^{d} & : \text { differencing non seasonal } \\ \left(1-B^{S}\right)^{D} & : \text { differencing seasonal } \\ \theta_{q}(B) & : \text { MA non seasonal } \\ \Theta_{Q}\left(B^{S}\right) & : \text { MA seasonal }\end{array}$

\subsection{Penelitian Terdahulu}

Peramalan data IHK cukup banyak dilakukan dengan menggunakan model ARIMA, salah satunya peramalan IHK Bangladesh dengan model ARIMA $(1,1,1)(1,0,1)_{12}$ diperoleh akurasi peramalan berdasarkan nilai Mean Average Percentage Error (MAPE) sekitar 0,08 persen [5].

Sementara itu, perbandingan metode SSA dan SARIMA oleh [4] untuk meramalkan tingkat kematian bulanan akibat kecelakaan di USA menunjukkan bahwa metode SSA memiliki akurasi paling baik dibandingkan metode SARIMA. Hal tersebut dapat dilihat dari nilai Mean Relative Average Error (MRAE) untuk SSA sekitar 2 persen dan SARIMA sekitar 6 persen.

\section{Metode Penelitian}

\subsection{Pengecekan Pola Musiman}

Tahapan dalam pengujian pola musiman yaitu [7]:

1. Tentukan koefisien pembeda $(d)$

2. Jika nilai $\mathrm{d}>0.5$ maka lakukan pembedaan terlebih dahulu

3. Tentukan nilai Frekuensi Fourier

$$
\omega_{k}=\frac{2 \pi k}{N} \text {, dengan } k=1,2, \ldots, \frac{N}{2}
$$

4. Tentukan nilai periode dari

$$
P_{k}=\frac{2 * \pi}{\omega_{k}}
$$

dari setiap $\omega_{k}$ 
5. Tentukan nilai periodogram (nilai periodogram akan menghasilkan nilai $\alpha$ dan $\beta$

6. Tentukan hipotesis penelitian yaitu

$\mathrm{H}_{0}: \alpha=\beta$ (ada pola musiman)

$\mathrm{H}_{1}: \alpha \neq \beta$ (tidak ada pola musiman)

Statistik uji:

$$
\begin{gathered}
F=\frac{(n-3)\left(\alpha_{k}^{2}+\beta_{k}^{2}\right)}{2 \sum_{\substack{j-1 \\
j \neq \neq}}^{n 2}\left(\alpha_{k}^{2}+\beta_{k}^{2}\right)} \\
\text { dengan } j=1,2, \ldots, \frac{n-1}{2} \text { dan } k=\frac{n}{2}
\end{gathered}
$$

Kriteria Uji : Tolak Ho jika $F_{\text {Hitung }}>F_{\text {Tabel(2,n-3; } \alpha)}$ dengan taraf signifikansi $\alpha$.

\subsection{Tahapan SSA}

Tahapan dasar SSA terdiri dari 2 tahap, yaitu: dekomposisi dan rekonstruksi. Tahap dekomposisi terdiri dari proses embedding dan SVD. Embedding mendekomposisi data time series awal ke dalam matriks lintasan yang akan membentuk pola tren, musiman, komponen bulanan, dan eror sesuai dengan nilai singularnya. Tahap rekonstruksi mencakup pengelompokan yang berdasar dari dekomposisi matriks lintasan dan proses diagonal averaging untuk merkonstruksi data time series baru dari pengelompokan yang sudah dilakukan sebelumnya.

\section{- Dekomposisi}

\section{- Embedding}

Pada tahap embedding, data time series awal $\mathbf{X}=\left(x_{1}, x_{2}, \ldots, x_{N}\right)$ diubah ke dalam bentuk matriks lintasan. Matriks lintasan yang dibentuk adalah:

$$
\boldsymbol{T}_{\boldsymbol{i}, \boldsymbol{j}}=\left(\begin{array}{cccc}
x_{1} & x_{2} & \cdots x_{L} \\
\vdots & \vdots & \ddots & \vdots \\
x_{K} & x_{K+1} & \cdots x_{N}
\end{array}\right)
$$

Matriks lintasan $\boldsymbol{T}_{\boldsymbol{X}}$ berdimensi $L \quad x \quad K$ dimana $\mathrm{L}$ adalah window length dengan $2<L$ $<N / 2$ dan $\mathrm{K}=\mathrm{N}-\mathrm{L}+1$

\section{- Singular Value Decomposition (SVD)}

Pada tahap ini, $\boldsymbol{T}_{\boldsymbol{X}}$ didekomposisi menjadi $\boldsymbol{T}_{X}=\boldsymbol{U} \boldsymbol{D} \boldsymbol{V}$ ' yang disebut dengan tirple eigen. Atau dapat ditulis menjadi:

$$
\begin{aligned}
T_{X}= & T_{1}+\cdots+T_{d} \\
& =U_{1} \sqrt{\lambda_{1}} V_{1}^{T}+\cdots+U_{d} \sqrt{\lambda_{d}} V_{d}^{T} \\
& =\sum_{i=1}^{d} U_{i} \sqrt{\lambda_{i}} V_{i}^{T}
\end{aligned}
$$

\section{- Rekonstruksi \\ - Grouping}

Pada tahap ini, matriks $\mathbf{T}_{\mathbf{i}}$ yang berdimensi LxK diekstrak ke dalam pola tren, musiman, komponen bulanan dan eror. Tahap pengelompokan merupakan partisi himpunan dari indeks $\{I, \ldots, d\}$ ke dalam kelompok himpunan disjoin $\mathrm{m}$ dari $\mathrm{I}=\left\{\mathrm{I}_{1}, \ldots, \mathrm{I}_{\mathrm{m}}\right\}$. Jadi $\mathrm{T}_{\mathrm{I}}$ berkorespondensi dengan kelompok $\mathrm{I}=\left\{I_{l}, \ldots\right.$, $\left.I_{m}\right\} . T_{I_{i}}$ adalah jumlah dari $T_{j}$ dimana $j \in I_{i}$.

Sehingga $T_{X}$ dapat dijabarkan menjadi:

$$
T_{X}=T_{1}+\cdots+T_{L}=T_{I_{1}}+\cdots+T_{I_{m}}
$$

\section{- Diagonal Averaging}

Pada diagonal averaging matriks $\mathrm{T}_{\mathrm{I}}$ yang telah dikelompokkan akan ditransformasi menjadi data deret berkala yang baru dengan panjang $\mathrm{N}$ dengan ketentuan berikut:

$$
\tilde{T}_{i, j}\left\{\begin{array}{cl}
\frac{1}{s-1} \sum_{j=1}^{s-1} x_{j, s-j} & \text { untuk } \\
\frac{1}{L} \sum_{j=1}^{L} x_{j, s-j} & \text { untuk } \\
\frac{1}{N-s+2} \sum_{j=s-K}^{N-s+2} x_{j, s-j} & \leq \mathrm{K}+1 \\
& \mathrm{Kn}+2 \leq \mathrm{s} \leq \\
& \mathrm{N}+1
\end{array}\right.
$$

\subsection{Peramalan SSA}

Peramalan SSA pada penelitian ini menggunakan model Linear Reccurance Relations (LRR) bentuk polynomial yang dapat dituliskan dalam bentuk berikut:

$$
y_{i+d}=\sum_{k=1}^{d} a_{k} y_{i+d-k}: 1 \leq i \leq N-d
$$

Koefisien LRF $a_{\mathrm{j}}$ diperoleh dari persamaan:

$$
\begin{aligned}
\Re & =\left(a_{L-1}, a_{L-2}, \ldots, a_{2}, a_{1}\right)^{T} \\
& =\frac{1}{1-v^{2}} \sum_{i=1}^{r} \pi_{i} U^{\nabla}
\end{aligned}
$$

\subsection{SARIMA}

SARIMA merupakan model parametrik sehingga diperlukan beberapa uji asumsi yang harus dipenuhi, diantaranya:

a. Stasioneritas.

Data deret waktu disebut stasioner jika nilai rata-rata dan varians konstan di sepanjang waktu. 
Prosedur uji stasioneritas dalam mean dengan uji Augmented Dickey Fuller (ADF):

H0 : $\rho=0$ (Terdapat unit roots, variabel $\mathrm{Z}$ tidak stasioner)

H1 : $\rho \neq 0$ (Tidak terdapat unit roots, variabel $\mathrm{Z}$ stasioner)

Statistik uji: $\tau=\frac{\widehat{\rho}}{s t d(\widehat{\rho})}$

dan hasil statistik hitungnya dibandingkan dengan tabel $\tau_{\alpha}$

b. Uji Normalitas. Pengujian kenormalan dapat dilakukan dengan uji Shapiro Wilk.

Hipotesis:

$H_{0}$ : residual berdistibusi normal

$H_{1}$ : residual tidak berdistribusi normal

c. Uji White Noise. Suatu model bersifat white noise artinya residual dari model tersebut telah memenuhi asumsi variasi residual homogen serta antar residual tidak berkorelasi.

Hipotesis:

$\mathrm{H} 0: \rho_{1}=\rho_{2}=\cdots=\rho_{k}=0$

H1 : Minimal ada satu $\rho_{i}$ sama dengan nol; $\mathrm{i}=1.2 \ldots ., \mathrm{k}$

Statistik uji (uji Ljung-Box):

$Q=n(n+2) \sum_{k=1}^{K} \frac{\widehat{\rho}_{k}{ }^{2}}{n-k} ; n>k$

Wilayah kritis:

$$
Q>\chi_{(\alpha ; K-p-q)}^{2}
$$

dengan:

$\begin{array}{ll}\mathrm{K} & \text { : lag maksimum } \\ \mathrm{n} & \text { : jumlah data (observasi) } \\ \mathrm{k} & : \text { lag ke-k } \\ \mathrm{p}, \mathrm{q} & \text { : order dari ARMA }(\mathrm{p}, \mathrm{q}) \\ \hat{\rho}_{k} & \text { : autokorelasi residual lag ke-k }\end{array}$

\subsection{Ukuran Ketepatan Peramalan}

MAPE merupakan ukuran yang dipakai untuk mengetahui persentase penyimpangan hasil peramalan. Jika $X_{i}$ adalah data aktual untuk periode $\mathrm{i}$ dan $F_{i}$ adalah hasil peramalan untuk periode yang sama, maka MAPE dapat dihitung dengan formula berikut:

$$
M A P E=\frac{1}{n} \sum_{i=1}^{n}\left|\left(\frac{X_{i}-F_{i}}{X_{i}}\right) x 100 \%\right|
$$

Interpretasi dari hasil perhitungan MAPE yaitu [8]:

$<10 \%$ : highly accurate forecasting

10\%-20\% : good forecasting

20\%-50\% : reasonable forecasting

$>50 \%$ : weak and inaccurate predictability

\subsection{Ukuran Keandalan Peramalan}

Tracking signal adalah ukuran toleransi yang digunakan untuk menentukan sampai periode ke berapa peramalan dapat dilakukan. Jika nilai-nilai tracking signal berada diuar batas yang dapat diterima yaitu \pm 5 maka model peramalan harus ditinjau kembali [9].

Tracking signal dapat dihitung dengan formula:

Tracking Signal $=\frac{\sum_{1}^{n} e_{n}}{\sum_{1}^{n} \frac{\left|e_{n}\right|}{n}}$

\section{Pembahasan Hasil}

\subsection{Gambaran IHK Kota Padangsidempuan}

Penelitian ini menggunakan data IHK Kota Padangsidempuan periode bulanan mulai Januari 2008 sampai November 2016 yang diperoleh dari web BPS Kota Padangsidempuan [10].

Perkembangan IHK Kota Padangsidempuan pada Januari 2008 sampai November 2016 yang disajikan pada gambar 1 menunjukkan pola tren dan juga terjadi volatilitas nilai indeks di setiap bulannya. Fenomena ini mengindikasikan bahwa indeks harga sepanjang tahun 2008 hingga akhir 2016 cenderung terus meningkat serta terjadi fluktuasi yang disebabkan adanya perubahan harga komoditas. Perubahan harga tersebut disebabkan oleh adanya intervensi pemerintah, adanya efek musiman seperti bulan Ramadhan, Idul Fitri, tahun ajaran baru dan faktor lainnya.

Keadaan IHK Kota Padangsidempuan sebelum periode Juni 2012 menunjukkan nilai indeks di bawah 100, hal ini mengindikasikan bahwa kondisi harga barang dan jasa secara umum di Kota Padangsidempuan sebelum periode Juni 2012 lebih murah dibandingkan setelah Juli 2012. Begitu pula sebaliknya, data IHK setelah Juli 2012 menunjukkan nilai indeks di atas 100 yang mengindikasikan harga barang dan jasa secara umum lebih mahal dibandingkan keadaan tahun 2012 yang merupakan dasar.

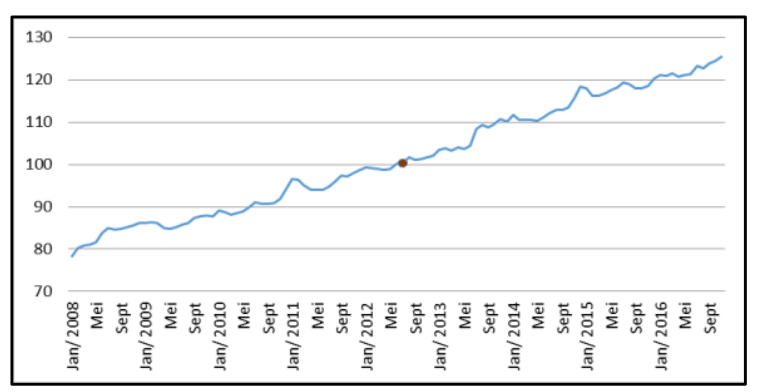

Gambar 1. Perkembangan IHK

Kota Padang Sidempuan Tahun 2008-2016 


\subsection{Pengujian Pola Musiman}

Pada gambar 1 perkembangan data IHK Kota Padangsidempuan memiliki pola tren yang jelas, akan tetapi untuk melihat pola musiman perlu dilakukan pengujian secara statistik.

Pengujian dengan menggunakan formula (1), (2) dan (3) serta dengan bantuan software R diperoleh hasil bahwa data IHK Kota Padang Sidempuan mengikuti pola musiman dengan periode 6 bulanan atau semesteran.

\subsection{Singular Spectral Analysis}

\subsubsection{Embedding}

Pada tahap ini akan diperoleh matriks lintasan untuk kemudian didekomposisi sesuai dengan nilai singularnya. Namun sebelumnya, harus ditentukan terlebih dahulu window length (L)-nya. Penentuan nilai window length ( $L$ ) dilakukan dengan tracking dalam dua tahap yaitu tahap pertama menghitung MAPE terkecil pada window length nilai puluhan, kemudian setelah mendapat window length terbaik pada tahap satu maka dilakukan tracking tahap dua dengan mencari nilai satuan lima keatas dan lima kebawah.

Tabel 1. Tracking Tahap I Windows Length

\begin{tabular}{|c|c|c|c|c|c|}
\hline L & L=10 & L=20 & L=30 & L=40 & L=50 \\
\hline MAPE & 2,302 & 0,917 & 0,949 & 1,529 & 1,997 \\
\hline
\end{tabular}

Dari tabel 1 dapat terlihat bahwa window length dengan nilai 20 menunjukkan nilai MAPE terkecil, yaitu $0,917 \%$. Tracking window length dilakukan lagi dengan mencari nilai satuan terkecil diantara nilai 20. Proses tracking window length tahap II dapat dilihat pada tabel berikut.

Tabel 2. Tracking Tahap II Windows Length

\begin{tabular}{|c|c|c|c|}
\hline $\mathbf{L}$ & MAPE & L & MAPE \\
\hline 15 & 1,257 & 21 & 1,118 \\
\hline 16 & 1,764 & 22 & 0,925 \\
\hline 17 & 1,861 & 23 & 1,002 \\
\hline 18 & 1,475 & 24 & 0,770 \\
\hline 19 & 1,202 & 25 & 0,958 \\
\hline
\end{tabular}

Tabel 2 menunjukkan nilai MAPE antara windows length 21-25 pada proses tracking signal tahap II. Dari tabel 2 tersebut diperoleh bahwa window length dengan $\mathrm{L}=24$ menunjukkan nilai MAPE terkecil sehingga dapat dikatakan bahwa dalam penelitian ini window length yang terbaik adalah 24 dan matriks lintasan yang terbentuk berukuran $24 \times 78$, yaitu:

$$
\left|\begin{array}{cccc}
78,23 & 80,32 & \ldots & 87.74 \\
80,32 & 80,91 & \ldots & 89.15 \\
\vdots & \ddots & & \ddots \\
87.74 & 89.15 & \ldots & 121,04
\end{array}\right|
$$

\subsubsection{SVD}

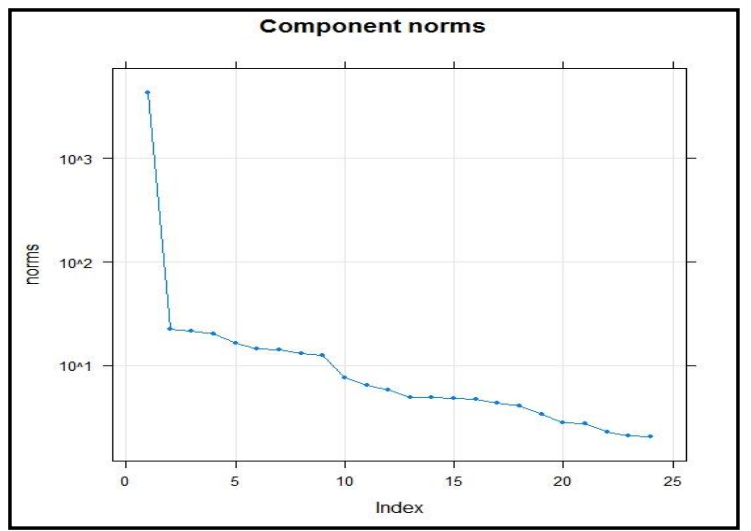

Gambar 2. Plot Eigen Value

Pada tahap SVD terbentuk eigen value dan eigen vector dari matriks lintasan. Eigen value yang diperoleh disajikan dalam gambar 2 berikut.

Dari gambar 2 dapat dilihat bahwa nilai eigen value untuk $\mathrm{L}_{1}=4346,124$ merupakan nilai terbesar yang berarti yang berarti eigenvalue dari $\mathrm{L}_{1}$ memberikan pengaruh terbesar dari komponen deret waktu terhadap karakteristik data dibandingkan dengan yang lainnya. Hal ini dapat juga diartikan bahwa pengaruh komponen pertama sangat besar pada pembentukan rekonstruksi sinyal. Eigenvalue selanjutnya cukup jauh berbeda dengan yang pertama dan cenderung menurun. Dari penurunan ini dapat diketahui dua hal, yaitu komponen periodik dan noise. Komponen periodik dengan periodesasi yang berbeda akan memiliki nilai singular yang berdekatan [4]. Ini terjadi pada nilai singular 1 hingga 15. Sedangkan penurunan perlahan (eigenvalue 16 sampai 24) menunjukkan adanya noise.

\subsubsection{Grouping}

Proses pengelompokan masih bersifat subjektif yang dilakukan berdasarkan plot berpasangan dari eigen vector. Plot yang berbentuk simetris mengindikasikan pola trend dan musiman sedangkan plot yang berbentuk random menunjukkan noise. 


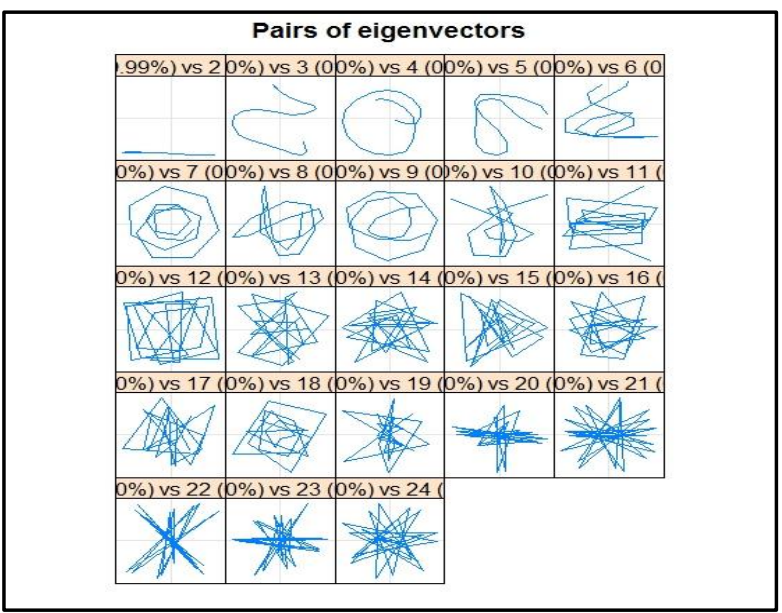

Gambar 3. Plot Berpasangan Eigen Vector

Berdasarkan gambar 3, terlihat bahwa pasangan eigenvector 1-15 adalah gabungan pola tren dengan pola periodik. Komponen trend dan periodik tidak dapat digabungkan menjadi satu kelompok karena akan terdapat noise. Komponen trend menjadi tidak halus karena masih mengandung komponen periodik [11].

Grouping dilakukan sampai periode ke-15. Hal ini dapat disimpulkan dari pola sudah tidak dapat diidentifikasi lagi (berpola acak) Berdasarkan identifikasi diatas, dengan window lenght $\mathrm{L}=24$ terbentuk sebanyak 4 grup yang terdiri dari 1 group trend dan 3 group musiman. Komponen yang terhimpun dalam masingmasing group disajikan dalam tabel 3 .

Tabel 3. Pengelompokan Komponen

\begin{tabular}{|c|c|c|}
\hline Grup & Komponen & Eigentriple \\
\hline 1 & Trend & 1 \\
\hline 2 & Season 1 & $2-6$ \\
\hline 3 & Season 2 & $6-9$ \\
\hline 4 & Season 3 & $10-15$ \\
\hline
\end{tabular}

Berdasarkan group yang telah terbentuk akan dilakukan pengecekan weak seperability antar group untuk memastikan bahwa antar group sudah tidak ada korelasi yang kuat.

Pada gambar 4 tampak bahwa hubungan antar group cukup lemah yang ditandai dengan korelasi antar group yang terarsir abu-abu.

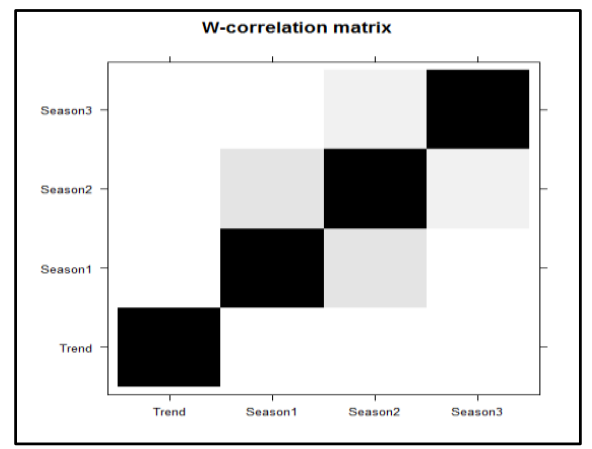

Gambar 4. Plot Matriks Korelasi Antar Group

\subsubsection{Diagonal Averaging}

Tabel 4. Proses Perhitungan Diagonal Averaging

\begin{tabular}{|c|c|c|c|c|c|c|c|}
\hline \multirow{2}{*}{$t$} & \multirow{2}{*}{ IHK Aktual } & \multicolumn{4}{|c|}{ Rekonstruksi } & \multirow{2}{*}{$\begin{array}{c}\text { Diagonal } \\
\text { Averaging }\end{array}$} & \multirow{2}{*}{ Residual } \\
\hline & & Tren & Season 1 & Season 2 & Season 3 & & \\
\hline 1 & 78.23 & 80.609 & -1.121 & -0.418 & -0.440 & 78.63 & -0.400 \\
\hline 2 & 80.32 & 81.004 & -0.753 & -0.336 & 0.200 & 80.115 & 0.205 \\
\hline \multirow[t]{2}{*}{3} & 80.91 & 81.365 & -0.489 & -0.316 & 0.198 & 80.758 & 0.152 \\
\hline & $\ldots$ & $\ldots$ & $\ldots$ & $\ldots$ & $\ldots$ & $\ldots$ & $\ldots$ \\
\hline 99 & 121.51 & 122.187 & -1.227 & 0.152 & 0.219 & 121.194 & 0.316 \\
\hline 100 & 120.67 & 122.654 & 1.731 & -0.008 & 0.167 & 121.082 & -0.412 \\
\hline 101 & 121.04 & 123.130 & -1.970 & 0.342 & -0.613 & 120.889 & 0.151 \\
\hline
\end{tabular}

Pada tahap ini, hasil dari ekspansi matriks berdasarkan proses grouping dijumlahkan untuk dihitung sesuai perhitungan diagonal averaging agar memperoleh deret baru. Perhitungan diagonal averaging mengunakan hasil penjumlahan matriks ekspansi yang menghasilkan deret baru. Proses perhitungannya dapat dilihat pada tabel 4 berikut.

\subsection{Peramalan SSA}

Koefisien Linear Recurrent Formula $\left(\mathrm{a}_{\mathrm{j}}\right)$ yang diperoleh dari persamaan (12) yaitu:

Tabel 5. Koefisien Linear Recurrent Formula $\left(a_{j}\right)$

\begin{tabular}{|c|c|c|c|c|c|}
\hline No. & $a_{j}$ & No. & $a_{j}$ & No. & $a_{j}$ \\
\hline 1 & -0.065 & 9 & 0.023 & 17 & -0.059 \\
\hline 2 & -0.073 & 10 & 0.072 & 18 & 0.054 \\
\hline 3 & -0.032 & 11 & -0.118 & 19 & -0.013 \\
\hline 4 & 0.215 & 12 & -0.075 & 20 & 0.013 \\
\hline 5 & -0.021 & 13 & 0.126 & 21 & 0.003 \\
\hline 6 & -0.216 & 14 & 0.000 & 22 & -0.250 \\
\hline 7 & -0.022 & 15 & 0.044 & 23 & 0.302 \\
\hline 8 & 0.007 & 16 & -0.058 & \multicolumn{1}{|c}{} \\
\cline { 1 - 3 } & & &
\end{tabular}


Dengan menggunakan persamaan (11) dan koefisien pada tabel 5 akan diperoleh hasil peramalannya.

\subsection{SARIMA}

Pada tahap awal, dilakukan pengecekan stasioneritas data dengan uji ADF dan diperoleh nilai $p$-value $=0.357$. Sehingga disimpulkan data tidak stasioner. Selanjutnya data akan didiffrencing pada $d=1$ agar data stasioner dalam mean. Setelah data di-diffrencing maka data IHK sudah stasioner, hal ini dapat dibuktikan jika dilakukan uji ADF pada data $d=1$ maka diperoleh nilai $p$-value $=0.01$ yang berarti data sudah stasioner.

Selanjutnya, dilakukan plot ACF dan PACF untuk identifikasi awal orde ARIMA.
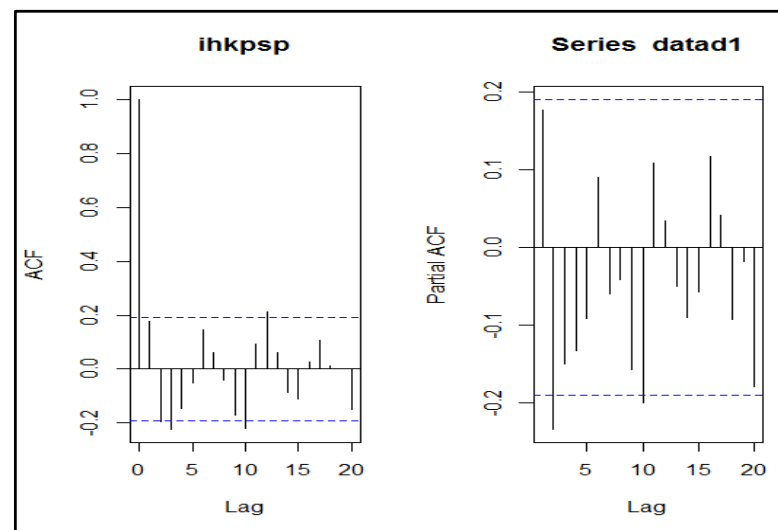

Gambar 5. Plot ACF dan PACF

Plot ACF pada gambar 5 menunjukkan cut off terjadi pada lag ke-3 yang berarti orde MA bernilai $\mathrm{p}=3$, sedangkan pada plot PACF terjadi cutoff pada lag ke-2 yang berarti orde AR bernilai $\mathrm{q}=2$. Sehingga identifikasi model SARIMA sementara adalah $(2,1,3)(2,1,3)$. Selanjutnya akan dilakukan uji coba model SARIMA beberapa orde dengan software $\mathrm{R}$ untuk memperoleh model terbaik dan memenuhi uji asumsi.

Tabel 6. Hasil Simulasi SARIMA dan Uji Asumsi

\begin{tabular}{|c|c|c|c|c|}
\hline $\begin{array}{c}\text { Model } \\
\text { SARIMA }\end{array}$ & AIC & $\begin{array}{c}\text { Signifikan } \\
\text { Koef. } \\
\text { Model }\end{array}$ & $\begin{array}{c}\text { White } \\
\text { Noise }\end{array}$ & $\begin{array}{c}\text { Residual } \\
\text { Normal }\end{array}$ \\
\hline $\begin{array}{c}(2,1,3) \\
(2,1,3)_{6}\end{array}$ & 245.9 & Ya & Ya & Tidak \\
\hline $\begin{array}{c}(1,1,1) \\
(0,1,1)_{6}\end{array}$ & 243.3 & Tidak & Ya & Ya \\
\hline $\begin{array}{c}(0,1,1) \\
(0,1,1)_{6}\end{array}$ & 243.0 & Ya & Ya & Ya \\
\hline
\end{tabular}

\begin{tabular}{|c|c|c|c|c|}
\hline $\begin{array}{c}(0,1,2) \\
(0,1,1)_{6}\end{array}$ & 242.8 & Tidak & Ya & Ya \\
\hline $\begin{array}{c}(0,1,3) \\
(0,1,1)_{6}\end{array}$ & 244.8 & Tidak & Ya & Ya \\
\hline $\begin{array}{c}(0,1,2) \\
(0,1,2)_{6}\end{array}$ & 244.7 & Ya & Ya & Ya \\
\hline $\begin{array}{c}(0,1,1) \\
(0,1,2)_{6}\end{array}$ & 244.9 & Ya & Ya & Ya \\
\hline $\begin{array}{c}(0,1,1) \\
(1,1,2)_{6}\end{array}$ & 264.1 & Ya & Ya & Ya \\
\hline
\end{tabular}

Dari tabel 6 diatas, diperoleh model terbaik yang memiliki nilai AIC terkecil dan memenuhi semua uji asumsi yaitu model SARIMA $(0,1,1)(0,1,1)_{6}$. Model SARIMA $(0,1,1)(0,1,1)_{6}$ dapat dituliskan dalam persamaan berikut:

$$
\begin{aligned}
& (1-B)\left(1-B^{6}\right) Y_{t}=(1-0.2671 B)(1- \\
& \left.B^{6}\right) a_{t} .
\end{aligned}
$$

Selanjutnya, dengan model tersebut dapat dilakukan permalan IHK untuk beberapa bulan ke depan.

\subsection{Evaluasi Hasil Peramalan SSA Dengan Model SARIMA}

Dari hasil analisis dan pembahasan diatas, tingkat ketepatan dan kestabilan peramalan pada metode SSA dan SARIMA disajikan dalam tabel 7. Nilai MAPE dari kedua metode sangat kecil (dibawah 10 persen) sehingga bisa dikatakan peramalan dengan SSA dan SARIMA $(0,1,1)(0,1,1) 6$ tingkat akurasinya sangat tinggi. Hal ini sejalan dengan penelitian yang dilakukan sebelumnya oleh [4] bahwa metode SSA dan SARIMA sama-sama memiliki akurasi yang sangat tinggi dalam meramalkan jumlah kematian akibat kecelakaan di USA.

Sementara itu, berdasarkan nilai tracking signal diketahui bahwa permalan IHK Kota Padangsidempuan baik dengan metode SSA maupun SARIMA stabil pada peramalan hingga 5 bulan ke depan saja karena nilai tracking signal yang diperoleh antara -5 sampai +5 di setiap bulannya, sedangkan pada bulan ke-6 nilai tracking signal-nya sudah lebih besar dari 5 dimana hal ini mengindikasikan bahwa peramalan sudah tidak stabil pada bulan ke-6. 
Tabel 7. Tracking Signal Metode Peramalan SSA dan SARIMA

\begin{tabular}{|l|c|c|c|c|}
\hline \multirow{2}{*}{ Periode } & \multicolumn{2}{|c|}{ SSA Forecasting } & \multicolumn{2}{c|}{$\begin{array}{c}\text { SARIMA } \\
(\mathbf{0 , 1}, \mathbf{1})(\mathbf{0 , 1}, \mathbf{1}) 6\end{array}$} \\
\cline { 2 - 5 } & Resid. & $\begin{array}{c}\text { Tracking } \\
\text { Signal }\end{array}$ & Resid. & $\begin{array}{c}\text { Tracking } \\
\text { Signal }\end{array}$ \\
\hline $\begin{array}{l}\text { Des/ } \\
2016\end{array}$ & -1.179 & -1.000 & -0.699 & -1 \\
\hline $\begin{array}{l}\text { Jan/ } \\
2017\end{array}$ & -0.098 & -2.000 & 0.063 & -1.668 \\
\hline $\begin{array}{l}\text { Feb/ } \\
2017\end{array}$ & -0.825 & -3.000 & -0.581 & -2.717 \\
\hline $\begin{array}{l}\text { Mar/ } \\
2017\end{array}$ & 0.209 & -3.278 & 0.504 & -1.543 \\
\hline $\begin{array}{l}\text { Apr/ } \\
2017\end{array}$ & -0.605 & -4.285 & 1.050 & 0.581 \\
\hline $\begin{array}{l}\text { Mei/ } \\
2017\end{array}$ & -2.812 & -5.563 & 1.560 & 2.552 \\
\hline MAPE & \multicolumn{2}{|c|}{0,770} & \multicolumn{2}{|c|}{0,559} \\
\hline
\end{tabular}

Tabel 8. Perbandingan Hasil Peramalan Data IHK Kota Padangsidempuan dengan Metode SSA dan SARIMA

\begin{tabular}{|c|c|c|}
\hline \multirow{2}{*}{$\begin{array}{c}\text { Periode } \\
\text { Peramalan }\end{array}$} & \multicolumn{2}{|c|}{ Metode Peramalan } \\
\cline { 2 - 3 } & SSA Forecasting & $\begin{array}{c}\text { SARIMA } \\
(\mathbf{0 , 1 , 1 ) ( 0 , 1 , 1 ) 6}\end{array}$ \\
\hline Des/ 2016 & 122.499 & 122.0194 \\
\hline $\mathrm{Jan} / 2017$ & 123.328 & 123.1667 \\
\hline $\mathrm{Feb} / 2017$ & 123.555 & 123.3114 \\
\hline $\mathrm{Mar} / 2017$ & 123.541 & 123.2455 \\
\hline Apr/ 2017 & 124.975 & 123.3203 \\
\hline
\end{tabular}

Berdasarkan tabel 8 diatas, tampak bahwa hasil peramalan IHK Kota Padangsidempuan menunjukkan pola yang terus meningkat selama 5 bulan ke depan atau dapat juga dikatakan akan terjadi inflasi untuk 5 bulan ke depan. Hasil peramalan pada metode SSA menunjukkan akan terjadi inflasi yang cukup tinggi pada April 2017 sementara itu pada metode SARIMA menunjukkan inflasi yang terjadi selama lima bulan ke depan cenderung tidak begitu melonjak tinggi.

\section{Kesimpulan}

Berdasarkan hasil analisis yang dilakukan, dapat disimpulkan bahwa:

a. Dengan Singular Spectral Analysis data IHK Kota Padang Sidempuan memiliki length window (L) sebesar 24 dan group sebanyak 4 (1 kelompok trend dan 3 kelompok musiman) dengan periode musiman terjadi di setiap semester b. Ketepatan hasil peramalan data IHK Kota Padang Sidempuan dengan metode SSA dan SARIMA $(0,1,1)(0,1,1)_{6}$ sama-sama berada pada kategori highly accurate

c. Keandalan hasil peramalan data IHK Kota Padang Sidempuan dengan metode SSA dan SARIMA $(0,1,1)(0,1,1)_{6}$ sama-sama stabil/ andal untuk meramalkan IHK 5 bulan ke depan

d. Peramalan data IHK Kota Padang Sidempuan dengan metode SSA serta SARIMA $(0,1,1)(0,1,1)_{6}$ memiliki nilai yang tidak begitu jauh berbeda selama 4 bulan pertama. Namun peramalan pada bulan ke-5 dengan metode SSA menunjukkan peningkatan nilai IHK yang cukup tinggi atau terjadi inflasi yang cukup tinggi.

e. Peramalan IHK baik dengan metode SSA maupun SARIMA sama-sama memiliki pola trend atau akan terjadi inflasi selama 5 bulan ke depan

\section{Daftar Pustaka}

[1] Darmawan,G, dkk, Perbandingan peramalan pada model singular spectrum analysis, Studi kasus : Curah Hujan Kota Bandung Dan Sekitarnya, Seminar Nasional Universitas Muhammadiyah Purwokerto, 2015

[2] No Kang Myung, Singular Spectrum Analysis, Graduate Thesis, University of California, Los Angeles, 2009

[3] BPS Sumatera Utara, Sumatera Utara Dalam Angka 2016. Medan: BPS SUMUT, (2016)

[4] Hassani, H., Singular Spectrum Analysis: Methodology and Comparison, Journal of Data Science 5(2007), 239-257

[5] Akhter Tahsina, Short-Term Forecasting Inflation of Inflation in Bangladesh with Seasonal ARIMA Processes, Munich Personal RePec Archive No. 43729, 2013, diakses melalui https://mpra.ub.unimuenchen.de/43729/1/MPRA_paper_43729. pdf pada 15 Februari 2017

[6] Wei, W.W.S, Time Series Analysis Univariate and Multivariate Methods, 2nd Edition, Pearson Education Inc. (2006)

[7] Darmawan,G, Identifikasi Pola Data Curah Hujan Pada Proses Grouping Dalam Metode Singular Spectrum Analysis. Seminar Nasional Pendidikan Matematika 2016 
ISSN: 2527-3159

[8] Lewis, C.D, Industrial and business forecasting methods, Butterworths (1982)

[9] Abraham, Bovas and Johannes Ledolter, Statistical Methods for Forecasting, Wiley (1983)

[10] www.padangsidimpuankota.bps.go.id diakses pada 1 Februari 2017

[11] Sakinah, A. M., Perbandingan Stabilitas Hasil Peramalan Suhu Dengan R-Forecasting Dan V-Forecasting SSA Untuk Long Horizon, Tesis, Departemen Statistika, FMIPA UNPAD (2013) 